\title{
The effects of $\boldsymbol{\beta}$-amino-butyric acid on resistance of cucumber against root-knot nematode, Meloidogyne javanica
}

\author{
Navazollah Sahebani • Najmeh Sadat Hadavi • \\ Fahimeh Omran Zade
}

Received: 14 December 2009/Revised: 20 June 2010/ Accepted: 14 July 2010 / Published online: 29 July 2010

(C) The Author(s) 2010. This article is published with open access at Springerlink.com

\begin{abstract}
In this study, the effects of $\beta$-amino-butyric acid (BABA) on root-knot nematode(Meloidogyne javanica) infection of cucumber and accumulation of total phenolic compounds, hydrogen peroxide and activity of some enzymes related to plant defense mechanisms, i.e., guaiacol peroxidase (GPOX), polyphenol oxidase (PPO), catalase (CAT) in cucumber roots infected with nematode were investigated. Results of this study show that treating the cucumber seedlings with the above elicitor significantly reduces the nematode infection level (the nematode galls, number of egg masses per plant and number of eggs per individual egg mass) compared to control. Additionally, treatment of cucumber roots by BABA and BABA + nematode, significantly increased peroxidase, polyphenol oxidase and catalase activities in root tissues, 1 day after nematode inoculation in comparison to nematode inoculated plants as control and sterile water-treated plants. Enzyme activities reached to a maximum level at 4, 4 and 3 days after nematode inoculation, respectively. Additionally, the amount of $\mathrm{H}_{2} \mathrm{O}_{2}$, a product of oxidative stress, was significantly increased in the $\mathrm{BABA}$ and $\mathrm{BABA}+$ nematode treatments in comparison to control. Such increases have occurred in two phases and maximum levels of it were observed at 5 days after inoculation. Inoculation of cucumber plants by BABA also significantly increased accumulation of total phenol in comparison to control and maximum level of it was observed at 7 days after nematode
\end{abstract}

Communicated by B. Barna.

N. Sahebani $(\bowtie) \cdot$ N. S. Hadavi · F. O. Zade

Department of Plant Protection,

University College of Aboureihan,

University of Tehran, PO Box 11365/4117, Tehran, Iran

e-mail: sahebani@ut.ac.ir inoculation. The results suggest that the inhibitory effect of BABA on the root-knot nematode (M. javanica) may be related to its ability to enhance defense responses in the cucumber roots.

Keywords Catalase $\cdot$ Hydrogen peroxide Peroxidase . Phenolic compounds · Polyphenol oxidase .

$\beta$-amino- $n$-butyric acid $\cdot$ Meloidogyne javanica

\section{Introduction}

Root-knot nematode (Meloidogyne spp.) is one of the most important nematode in field and greenhouse-grown crops. Among the alternative methods developed for management of the nematode, the use of induced plant defense mechanisms by utilizing chemical and microbial elicitors have shown increasing interests and researchers have applied it on a variety of crop plants. Over the last 30 years, a number of chemical compounds have been shown to increase disease resistance of plants. Salicylic acid (SA), and its functional analogs [isonicotinic acid (INA), benzothidiazoles (BTH)] and $\beta$-amino- $n$-butyric acid (BABA) are among the most thoroughly studied compounds for inducing disease resistance (Gorlach et al. 1996; He and Wolyn 2005; Sahebani and Hadavi 2009). These compounds activate resistance in many crops against plant diseases that are incited by a variety of pathogens including, fungi, bacteria, viruses, and nematodes (Kessmann et al. 1994; Cohen 1994; Oostendorp and Seikora 1990). Plant molecules thought to be plant defense signals, such as ethylene, systemin, jasmonic acid (JA) and methyl jasmonate (MeJA) also have been reported to induce local and systemic resistance in plants to several pathogens (Oka et al. 1999). For instance, Nandi et al. (2003) have used 
exogenous SA as plant inducer for suppression of Meloidogyne incognita infestation of okra and cowpea. They showed that foliar spray of SA significantly reduces the nematode gall and the number of eggs per gram of root tissue. Their study also shows a significant increase in activity of phenylalanine ammonia lyase and pathogenesisrelated protein-1 (PR-1) accumulation in roots. Cooper et al. (2005), however, have indicated that application of jasmonic acid as a plant-signaling compound to tomato foliage induces systemic effects on root-knot nematode and causes significant reduction in nematode egg masses/g root tissue. They believe that the mechanism through which JA suppresses nematode infestation is ought to be transported from foliage to roots.

BABA is a nonprotein amino acids have been used as plant inducers against a broad spectrum of pathogens in several crops (Oka et al. 1999; Lee et al. 2000). Oka et al. (1999) utilized the BABA as a resistance inducer in tomato. They have indicated that foliar spray and soil drenching with BABA causes local and systemic induction of plant defense mechanisms and reduces the root galling as well as the number of eggs. Ton et al. (2005) have shown that plants treated with BABA develop an enhanced capacity to resist biotic and abiotic stresses. They have also shown that induced resistance fails at low BABA concentration whereas female sterility occurs at high BABA concentrations. They have also suggested that defection in the priming for SA dependent defenses in plants (such as PR-1) reasonably correlates with defection in BABAinduced resistance. This leads to the consideration of $\mathrm{BABA}$ as an accelerator of the SA response pathway. The effects of BABA, Salicylic acid (SA), and Pseudomonas fluorecens $\mathrm{CHAO}$ on $\mathrm{H}_{2} \mathrm{O}_{2}$ generation and activity of the enzymes related to its metabolism, i.e., superoxide dismutase (SOD), guaiacol peroxidase (GPOX), and catalase (CAT) were investigated in tomato roots infected with root-knot nematode ( $M$. javanica) by Sahebani and Hadavi (2009). They showed that BABA has reduced the nematode infection level, $\mathrm{H}_{2} \mathrm{O}_{2}$ accumulation and the SOD and GPOX activities more than the other tested elicitors.

Activation of enzymes related to plant defenses against pathogens and accumulation of plant defense metabolites are the most important mechanisms of chemical inducers in related to plants. However, little work has been reported on how these chemical inducers may affect induction of defense compounds. As mentioned above, SA increases the activity of phenylalanine ammonia lyase and pathogenesisrelated protein-1 (PR-1) accumulation in roots. Many plant enzymes are involved in defense reactions against plant pathogens. One example is the peroxidase (POX) that belongs to an important enzyme system generating $\mathrm{H}_{2} \mathrm{O}_{2}$ which is also capable of reducing its level. This $\mathrm{H}_{2} \mathrm{O}_{2}$ level reduction can be accomplished during $\mathrm{H}_{2} \mathrm{O}_{2}$-dependent lignin biosynthesis (Ben Amor et al. 2005; Monties 1989; Vance et al. 1980) and $\mathrm{H}_{2} \mathrm{O}_{2}$-dependent cross-linking of cell wall proteins such as hydroxyproline rich glycoproteins (Iiyama et al. 1994). Catalase (CAT) also plays an important role in the catabolism of $\mathrm{H}_{2} \mathrm{O}_{2}$. This enzyme catalyses the dismutation of $\mathrm{H}_{2} \mathrm{O}_{2}$ into water and oxygen. The second role of CAT is peroxidative activity that is when one molecule of $\mathrm{H}_{2} \mathrm{O}_{2}$ and one molecule of hydrogen donor serve as substrates. According to Ben Amor et al. (2005), CAT plays the role of a specific GPOX protecting cell from toxic effects of $\mathrm{H}_{2} \mathrm{O}_{2}$. Zhang et al. (2007) used BABA as an inducer for the ability to reduce fusarium head blight of wheat in the green house condition. They showed that application BABA at concentration of $1 \mathrm{mM}$ significantly reduce disease severity.

The first objective of this study was to determine the effect of BABA as a plant defense inducer on the infection and reproduction of $M$. javanica on cucumber plant and secondly, to verify if the induced resistance mechanism is responsible for the capacity of BABA, to control root-knot nematode, $M$. javanica. The objectives of this study were addressed by monitoring the activity of peroxidase, polyphenol oxidase, catalase, and accumulation of total phenolic compounds and hydrogen peroxide, accepted markers of induced resistance.

\section{Materials and methods}

\section{Nematode inoculum preparation}

Infected sample was collected from a tomato field in Shiraz (Fars province, Iran) and single egg mass was used to establish a population on Rutgers tomato variety for the experiment. Eggs were extracted from infected tomato roots using $1 \% \mathrm{NaOCl}$. Extracted eggs were gently washed with tap water to remove $\mathrm{NaOCl}$ (Hussey and Barker 1973). The species of nematode was identified as $M$. javanica according to morphological and morphometrical characters Eisenback (1985).

\section{Plant material}

Experiments were carried out with cucumber (Cucumis sativus var. super Dominus) grown in a controlled-environment cabinet. The air temperature was maintained at $27^{\circ} \mathrm{C}$.

\section{Greenhouse experiments}

The cucumber seeds were surface sterilized with $1 \%$ sodium hypochlorite for $5 \mathrm{~min}$ and was sown in pots containing sterile soil containing sterile soil [mixture of field soil (silty clay; $78 \%$ organic matter) and sand (1:1 v/v)]. Seedlings with 4-6 leaves were soil drenched ( $25 \mathrm{ml}$ per plant) with 
BABA solution (10 mM). One day after treatment, seedlings were inoculated with 2000 nematode second juvenile (J2) per individual seedling (Oka et al. 1999), having sterile distilled water as control. Forty days after inoculation of seedlings with nematode, root and aerial portion weight of plants, number of galls and egg masses per seedling and the number of eggs per individual egg mass were evaluated. Other treatments in this experiment were: (1) cucumber seedling treated with sterile distilled water and (2) cucumber seedling treated with BABA. The experiment was performed as $\mathrm{RC}$ design with 10 replications.

Effect of BABA-treated root on some plant defense mechanisms

The cucumber seeds were surface sterilized as described above and were sown in pots $(1 \mathrm{~kg})$ containing sterile soil. Seedlings with 4-6 leaves were soil drenched (25 ml per plant) with BABA suspension $(10 \mathrm{mM})$, having sterile distilled water as control. One day later, seedlings were inoculated with 2,000 nematode second juvenile (J2) per individual seedling. Root sampling and measurement of $\mathrm{H}_{2} \mathrm{O}_{2}$ content, GPOX, PPO and CAT activities were carried out for 7 days and total phenolic compounds 9 days with 1 day intervals. Other treatments in this experiment were: (1) cucumber seedling treated with sterile distilled water and (2) cucumber seedling treated with BABA.

\section{Enzyme activity assays}

For measuring the enzyme activities, $0.5 \mathrm{~g}$ root tissue was homogenized in $5 \mathrm{ml}, 10 \mathrm{mM}$ potassium phosphate buffer $(\mathrm{pH} 7.0)$ containing $4 \%(\mathrm{w} / \mathrm{v})$ polyvinylpyrrolidone (MW $25,000)$. The homogenate was centrifuged at $12,000 \mathrm{~g}$ for $30 \mathrm{~min}$ and the obtained supernatant was, then, used as root extract. All steps in the preparation of the root extract were carried out at $0-4{ }^{\circ} \mathrm{C}$. An aliquot of the extract was used to determine its protein content using the method introduced by Bradford (1979) utilizing bovine serum albumin as standard. The supernatant to be used for peroxidase, polyphenol oxidase and catalase activity assay, was transferred to a $1.5 \mathrm{ml}$ vial and stored at $-40^{\circ} \mathrm{C}$.

\section{Peroxidase assay}

The POX activity was assayed by measuring the increase in absorbance at $\lambda_{\max }$ of $475 \mathrm{~nm}$ due to oxidation of guaiacol (Dias and Costa 1983). The $2 \mathrm{ml}$ reaction mixture used for this case consisted of $25 \mathrm{mM}$ of phosphate buffer with $\mathrm{pH}$ of 7.0, $0.05 \%$ guaiacol (w/v), $1.0 \mathrm{mM}$ of $\mathrm{H}_{2} \mathrm{O}_{2}, 0.1 \mathrm{mM}$ of EDTA, and $0.2 \mathrm{ml}$ of the root extract. Peroxidase activity was expressed as the change in absorbance of the reaction mixture at $475 \mathrm{~nm}$ per $\mathrm{mg}$ of total protein per min.

\section{Polyphenol oxidase assay}

The following reaction mixture $(2 \mathrm{ml})$ was used: crude extract (containing $40 \mu \mathrm{g}$ protein), $20 \mu \mathrm{L}$ of $500 \mathrm{mM}$ prolin and $25 \mathrm{mM}$ citrate phosphate buffer ( $\mathrm{pH} 6.4)$. The reaction was started by addition of $40 \mu \mathrm{L}$ of $1 \mathrm{M}$ catechol and the initial rate of increase in absorbency at $515 \mathrm{~nm}$ was measured over $1 \mathrm{~min}$. Polyphenol oxidase activity was expressed as the change in absorbance of the reaction mixture per mg of total protein per min (Mohammadi and Kazemi 2002).

\section{Catalase assay}

The CAT activity was assayed by measuring the rate of disappearance of $\mathrm{H}_{2} \mathrm{O}_{2}$ at $240 \mathrm{~nm}$ using the method proposed by Kato and Shimizu (1987). Three ml of catalase assay reaction mixture containing $10 \mathrm{mM}$ potassium phosphate buffer $(\mathrm{pH}=7.0), 0.1 \mathrm{ml}$ root extract, and $0.035 \mathrm{ml} \mathrm{H}_{2} \mathrm{O}_{2}(3 \%)$ are used. The observed decline in the optical density at $\lambda_{\max }$ of $240 \mathrm{~nm}$ was concluded to be an indication of the decrease in $\mathrm{H}_{2} \mathrm{O}_{2}$ content. Catalase activity was expressed as the change in absorbance of the reaction mixture per $\mathrm{mg}$ of total protein per min.

\section{$\mathrm{H}_{2} \mathrm{O}_{2}$ content assay}

Hydrogen peroxide levels were determined according to Velikova et al. (2000). Root tissues (500 mg) were homogenized in an ice bath with $5 \mathrm{ml} 0.1 \%$ (w/v) trichloracetic acid (TCA). The homogenate was centrifuged at $12,000 \mathrm{~g}$ for $15 \mathrm{~min}$ and $0.5 \mathrm{ml}$ of the supernatant was added to $0.5 \mathrm{ml}$, $10 \mathrm{mM}$ potassium phosphate buffer $(\mathrm{pH} 7.0)$ and $1 \mathrm{ml}, 1 \mathrm{M}$ KI. The absorbency of supernatant was read at $\lambda_{\max }=$ $390 \mathrm{~nm}$. The hydrogen peroxide content was calculated based on a standard curve made by measuring known hydrogen peroxide concentrations ranging from 0 to $1,000 \mu \mathrm{M}$ in the same assay.

\section{Total phenolic compounds assay}

Cucumber roots $(0.5 \mathrm{~g})$ were homogenized in $8 \mathrm{ml}$ of $80 \%$ acidified ethanol. The homogenate was centrifuged at $4,000 \mathrm{~g}$ at room temperature for $5 \mathrm{~min}$ and then $1 \mathrm{ml}$ of the methanolic supernatant was added to $5 \mathrm{ml}$ of distilled water and $250 \mu \mathrm{l}$ of Folin-Ciocalteu reagent (Merck), and the solution was incubated at room temperature. After $3 \mathrm{~min}, 1 \mathrm{ml}$ of a saturated solution of $\mathrm{Na}_{2} \mathrm{CO}_{3}$ and $1 \mathrm{ml}$ of distilled water was added and the reaction mixture was incubated for $1 \mathrm{~h}$. The absorbance of the developed blue color was measured at $725 \mathrm{~nm}$ using a blank, water and reagent only. Caffeic acid (Fluka) was used as reference phenolic compounds. The total phenolic compounds of samples were expressed as milligram caffeic acid per gram of root fresh weight (Malick and Singh 1980). 


\section{Isoperoxidase study}

Soluble peroxidase isozymes were studied in the manner of Seevers et al. (1971) with the following modification. Native-polyacrylamide gel electrophoresis (native-PAGE) with a $12 \%$ running and $6 \%$ stacking gel at $4{ }^{\circ} \mathrm{C}$ was carried out at 75 and $100 \mathrm{v}$ in stacking and running gel, respectively. The crude extract from above mentioned treatments was used in this study. Equal amount of total protein $(40 \mu \mathrm{g})$ from each treatment was added to each gel lane. After the dye front reached the end of running gel, the gel was treated with $200 \mathrm{ml}$ of $25 \mathrm{~mm}$ citrate-phosphate buffer, $\mathrm{pH}=5.4$, containing $5 \mathrm{~mm}$ guaiacol for $30 \mathrm{~min}$. Then, $2 \mathrm{ml}$ of $30 \%$ $\mathrm{H}_{2} \mathrm{O}_{2}$ was added dropwise with constant shaking until bands representing POX activity appeared. Immediately after resolution of bands, $R_{\mathrm{f}}$ value of each isozyme was determined and the gels were recorded photographically.

\section{Statistical analysis}

Growing, inoculation, and sampling of plants were performed twice and the mean of two assays was used for statistical analysis as the value of each replicate. Data were statistically analyzed, using the SAS version 9.0 (Statistical Analysis System Institute Inc., Cary, NC, USA), by ANOVA. Statistical significance between mean values was compared by Duncan's multiple range test $P$ values $<0.05$.

\section{Results}

Effects of application of BABA on $M$. javanica infection

The cucumber plants from nematode second juveniles (J2) infested soils treated with BABA exhibited a significant reduction in disease level (number of galls per plant) as well as the number of egg masses and number of eggs per individual egg mass per plant as compared with the control (Table 1), however, root and aerial portion fresh weight of cucumber treated with BABA were significantly increased compared nematode inoculated plants but with no significant difference with control and other treatment (Figs. 1, 2).

Changes in enzyme activities

As showed in Fig. 3, GPOX activity at an approximately equal level in $\mathrm{BABA}+$ nematode and $\mathrm{BABA}$ treatments started on the first day after inoculation and increased day by day, reaching the maximum at fourth day, followed by a gradual decrease thereafter. Significant differences were observed among these treatments in comparison to nematode inoculated roots and sterile distilled water-treated roots. GPOX activity also showed significant difference in nematode inoculated roots in comparison to sterile distilled water-treated roots in third and fourth day after nematode inoculation.

Figure 4 shows that PPO activity with significant difference increased in $\mathrm{BABA}+$ nematode treatment in comparison to all other treatments and nematode inoculated seedlings (control), during 1-4 days after inoculation and reached to maximum level at fourth day after inoculation and followed by a gradual decrease thereafter. Decreasing of PPO activity in BABA + nematode and nematode inoculated seedlings treatments were notably more than BABA-treated seedlings and specially 7 days after inoculation.

Catalase activity in BABA + nematode treatment as BABA-treated seedlings significantly increased during 1-3 days after nematode inoculation in comparison to nematode inoculated seedlings (control) and sterile distilled water-treated seedlings. Enzyme activity reached to maximum at 3 days after inoculation followed by a gradual decrease thereafter. Enzyme activity in nematode inoculated seedlings did not showed significant differences in comparison to sterile distilled water-treated seedlings (Fig. 5).

$\mathrm{H}_{2} \mathrm{O}_{2}$ content

Cucumber seedling treated with $\mathrm{BABA}+$ nematode and $\mathrm{BABA}$ alone showed significant increase in $\mathrm{H}_{2} \mathrm{O}_{2}$

Table 1 Effect of $\beta$-amino-butyric acid (BABA) on root-knot nematode (Meloidogyne javanica) disease severity (No. galls/plant, No. egg masses/plant and No. eggs/egg mass) on cucumber (Cucumis sativus var. super Dominus), under greenhouse conditions

\begin{tabular}{|c|c|c|c|}
\hline \multirow[t]{2}{*}{ Characters } & \multicolumn{3}{|l|}{ Treatments } \\
\hline & $\begin{array}{l}\text { Nematode }+ \text { sterile water } \\
\text { (control) }\end{array}$ & Nematode + BABA & $\operatorname{LSD}(P=0.05)$ \\
\hline No. galls/plant & $95 \pm 7$ & $35 \pm 5$ & 6.0 \\
\hline No. egg masses/plant & $135 \pm 26$ & $62 \pm 12$ & 13.2 \\
\hline No. eggs/egg mass & $587 \pm 24$ & $468 \pm 25$ & 18.4 \\
\hline
\end{tabular}

Data are the average of two trials each with ten replicated plants per treatment \pm standard error

LSD (least significant difference) calculated at $P \leq 0.05$ 


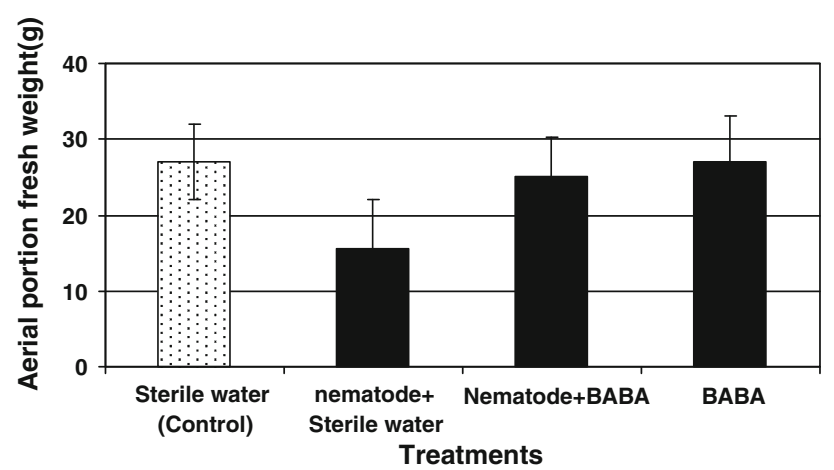

Fig. 1 Effect of $\beta$-amino-butyric acid (BABA) on root-knot nematode (Meloidogyne javanica) disease severity (aerial portion fresh weight) on cucumber (Cucumis sativus var. super Dominus), under greenhouse conditions. Data are the average of ten replicates. The values were significant according to Duncan's multiple range test $(P \leq 0.05)$. Error bars indicate $\pm \mathrm{SE}$

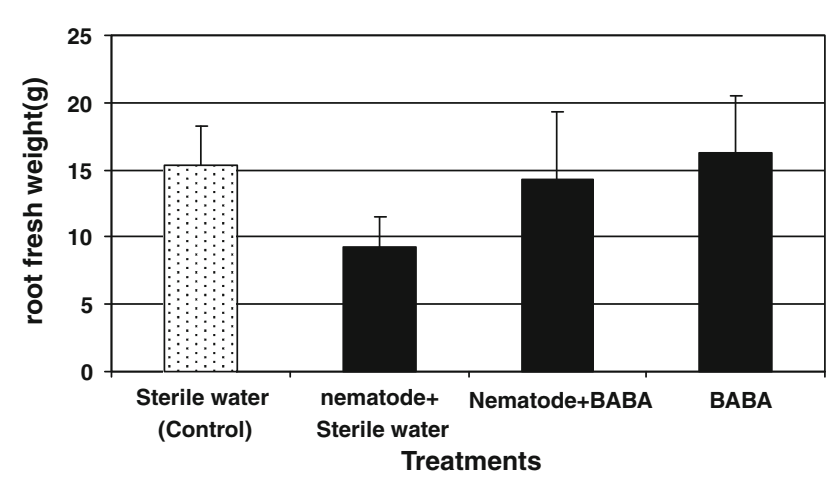

Fig. 2 Effect of $\beta$-amino-butyric acid (BABA) on root-knot nematode (Meloidogyne javanica) disease severity (root fresh weight) on cucumber (Cucumis sativus var. super Dominus), under greenhouse conditions. Data are the average of ten replicates. The values were significant according to Duncan's multiple range test $(P \leq 0.05)$. Error bars indicate $\pm \mathrm{SE}$

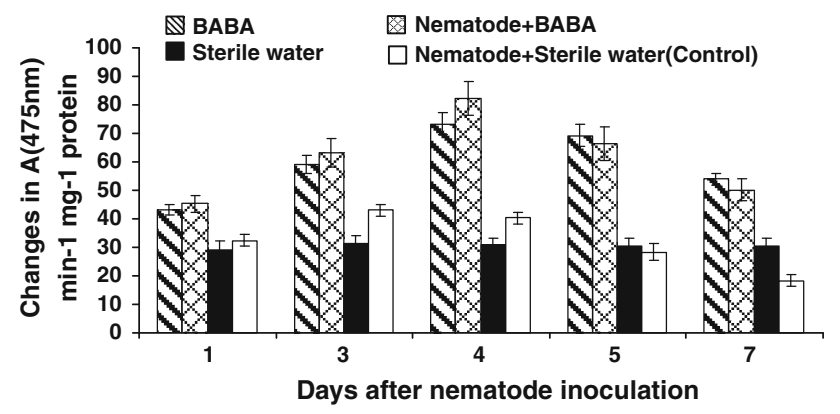

Fig. 3 Time course of changes in guaiacol peroxidase (GPOX) activity in the roots of cucumber (var. Super Dominus) treated with $\beta$-amino-butyric acid (BABA), BABA + root-knot nematode ( $\mathrm{Mel}$ oidogyne javanica), sterile water and in the control. Data are the average of ten replicates. The values were significant according to Duncan's multiple range test $(P \leq 0.05)$. Error bars indicate $\pm \mathrm{SE}$

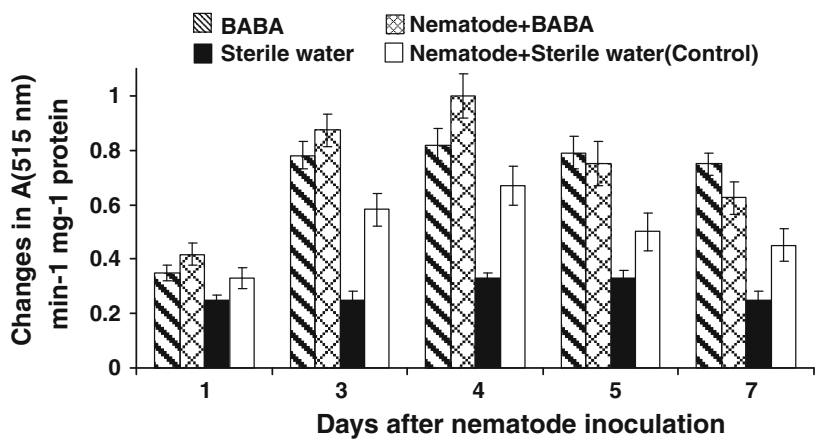

Fig. 4 Time course of changes in polyphenol oxidase (PPO) activity in the roots of cucumber (var. Super Dominus) treated with $\beta$-aminobutyric acid (BABA), BABA + root-knot nematode (Meloidogyne javanica), sterile water and in the control. Data are the average of ten replicates. The values were significant according to Duncan's multiple range test $(P \leq 0.05)$. Error bars indicate \pm SE

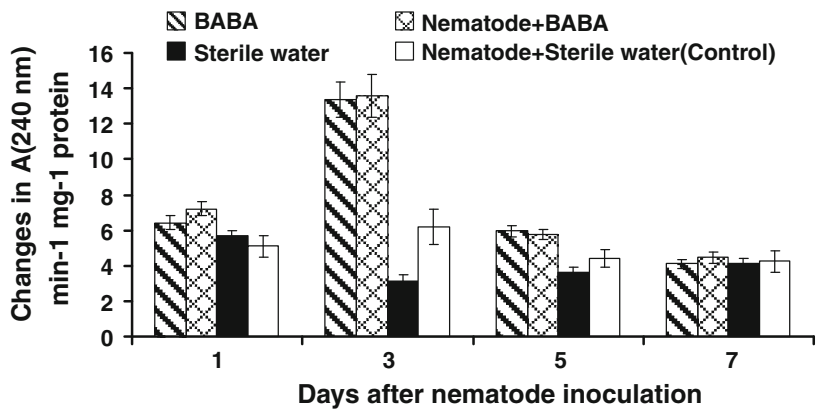

Fig. 5 Time course of changes in catalase (CAT) activity in the roots of cucumber (var. Super Dominus) treated with $\beta$-amino-butyric acid (BABA), BABA + root-knot nematode (Meloidogyne javanica), sterile water and in the control. Data are the average of ten replicates. The values were significant according to Duncan's multiple range test $(P \leq 0.05)$. Error bars indicate \pm SE

accumulation in comparison to nematode inoculated (control) and sterile distilled water-treated seedlings 1 day after inoculation, followed by a gradual decrease during 1-3 days after it. No significant differences were observed among all treatments during these days. Further increase in $\mathrm{H}_{2} \mathrm{O}_{2}$ accumulation occurred after 4 days and So accumulation of $\mathrm{H}_{2} \mathrm{O}_{2}$ elevated in two phases, i.e., early after treatment ( 1 day after treatment) and after 4 days (Fig. 6). Maximum level of $\mathrm{H}_{2} \mathrm{O}_{2}$ in this experiment was observed at fifth day after inoculation.

Total phenolic compounds content

Accumulation of total phenolic compounds in BABAtreated seedlings significantly increased during days after treatment in comparison to nematode inoculated (control) and sterile distilled water-treated seedlings and reached to a maximum level at 7 days after treatment and then followed 


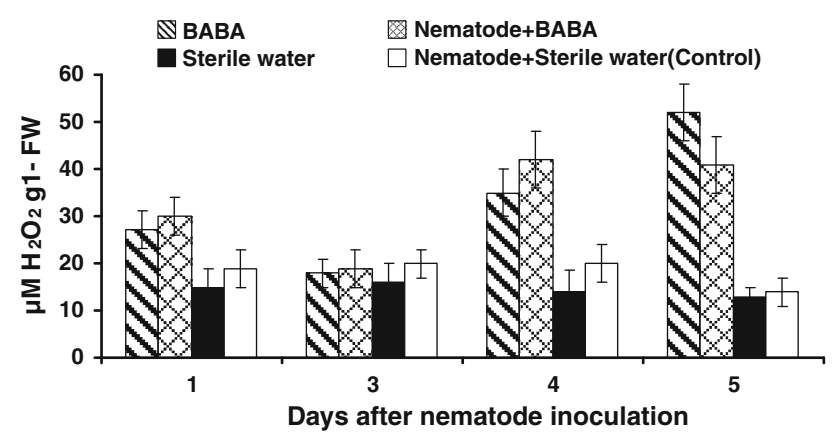

Fig. 6 Time course of hydrogen peroxide $\left(\mathrm{H}_{2} \mathrm{O}_{2}\right)$ accumulation in the roots of cucumber (var. Super Dominus) treated with $\beta$-amino-butyric acid (BABA), BABA + root-knot nematode (Meloidogyne javanica), sterile water and in the control. Data are the average of ten replicates. The values were significant according to Duncan's multiple range test $(P \leq 0.05)$. Error bars indicate $\pm \mathrm{SE}$

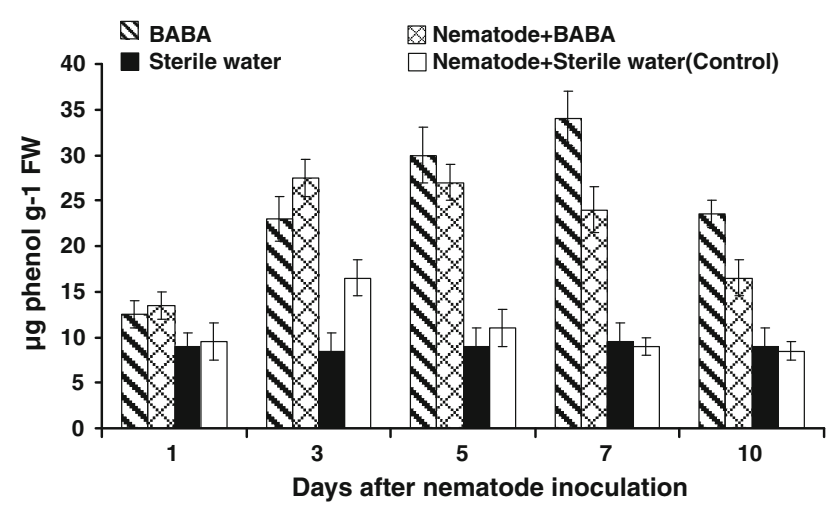

Fig. 7 Time course of total phenolic compound accumulation in the roots of cucumber (var. Super Dominus) treated with $\beta$-amino-butyric acid (BABA), BABA + root-knot nematode (Meloidogyne javanica), sterile water and in the control. Data are the average of ten replicates. The values were significant according to Duncan's multiple range test $(P \leq 0.05)$. Error bars indicate \pm SE

by a decrease. BABA + nematode treated increased accumulation of total phenolic compounds with significant differences compared to BABA-treated seedlings till 3 or 4 days after inoculation but followed by gradual decrease 4 or 5 days after nematode inoculation. Nematode inoculated seedlings did not showed significant differences in comparison to sterile distilled water-treated seedlings in all 10 days after nematode inoculation (Fig. 7).

\section{Isoperoxidase study}

Native-PAGE assay indicated that 4 acidic isozymes designated $R_{\mathrm{f}}=0.31,0.340 .36$ and 0.39 in cucumber roots could be activated by BABA and $M$. javanica. $R_{\mathrm{f}}=0.31$ with an equal intensity appeared in all treatments, but in BABA treated roots it was the lower among other treatment and control (inoculated with nematode). $R_{\mathrm{f}}=0.34$ band was condense in seedling root treated

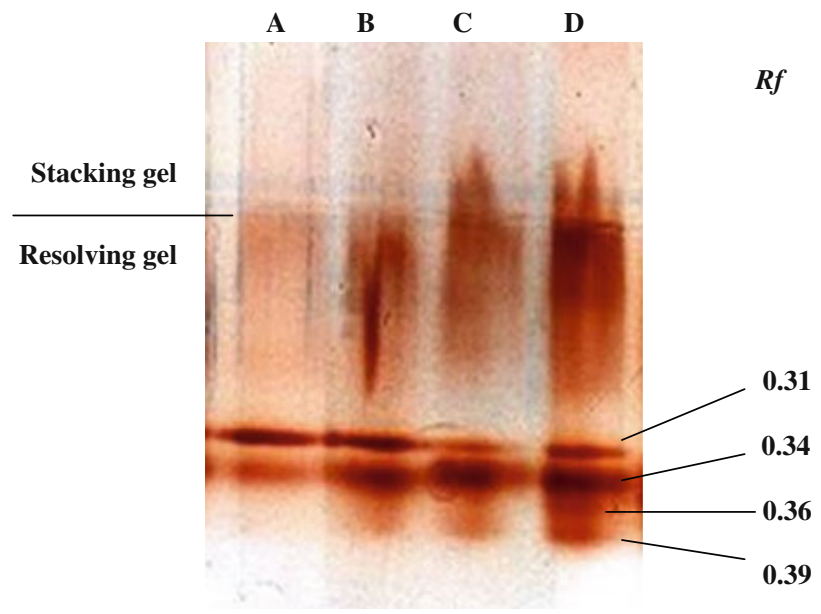

Fig. 8 Native-PAGE assay of soluble peroxidase isozyme. A SD/ water-treated root. $B$ Nematode-inoculated root (control). $C$ BABAtreated root. $D$ BABA- and nematode-inoculated roots. $R_{\mathrm{f}}$ distance of isozyme migration divided by distance of migration of the dye front

with $\mathrm{BABA}, \mathrm{BABA}+$ nematode and control, but weakly appeared in sterile distilled water treated root. This band was the highest in BABA + nematode inoculated roots. $R_{\mathrm{f}}=0.36$ and 0.39 isozymes were relatively condense in $\mathrm{BABA}+$ nematode inoculated roots in comparison to control (inoculated with nematode) and other treatments (Fig. 8).

\section{Discussion}

Induced resistance exploiting natural defense of plants could be proposed as an alternative approach for plant protection. This study assessed the effects of BABA on nematode infection and induction of some plant defense compounds in cucumber roots. BABA is a known chemical plant defense activator and has been used successfully to induce resistance against a wide spectrum of pathogens. This study showed that BABA stimulate the GPOX, PPO, CAT, $\mathrm{H}_{2} \mathrm{O}_{2}$ and total phenolic compounds in cucumber roots against root-knot nematode, $M$. javanica. Siegrist et al. (2000) showed that local spray application of BABA caused effective resistance to TMV in tobacco plants. They also showed that this resistance is associated with the rapid generation of superoxide and hydrogen peroxide, occurrence of lipid peroxidation in treated tissues, a local and systemic increase of salicylic acid (SA) levels and the expression of PR-1a, a molecular marker of SAR in tobacco. In previous studies, plant defense compounds such as pathogenesis-related (PR) proteins ( $\beta$-1,3-glucanase, chitinase) and salicylic acid were reported to increase in plants which were treated with BABA (Kook Hwang et al. 1997). POX and PPO catalyze the last step in the 
biosynthesis of lignin and other oxidative phenols. Also, POX is involved in the production or modulation of active oxygen species which may play various roles directly or indirectly in reducing pathogen viability and infection (Lamb and Dixon 1997). Studies have showed that peroxidases could be involved in production as well as scavenging of $\mathrm{H}_{2} \mathrm{O}_{2}$ (Kvaratskhelia et al. 1997; Velikova et al. 2000; Willekens et al. 1995), in reinforcement of cell walls (Vance et al. 1980), deposition of polyphenolics (Lagrimini 1991), and polymerization of suberins (Kato and Shimizu 1987). In addition, POX and PPO play a central role in triggering the hypersensitive reaction (HR), in the crosslinking and lignification of the cell wall and in transducing signals to adjacent non-challenged cells. The increased activation of PPO and POX could be detected in the cucumber leaf in the vicinity of lesions caused by some foliar pathogens or phosphate application (Avdiushko et al. 1993).

$\mathrm{H}_{2} \mathrm{O}_{2}$ accumulation could be considered as one of the many plant defense molecules and as a secondary messenger in the systemic signal network of plant cells (Shetty et al. 2003). The increase in $\mathrm{H}_{2} \mathrm{O}_{2}$ level may also cause pathogen destruction. Our observation shows that as a conspicuous host response, $\mathrm{H}_{2} \mathrm{O}_{2}$ accumulation occurred to a significantly higher degree in the $\mathrm{BABA}+$ nematode and BABA treated plants. Such increases have occurred in two phases and maximum levels of them were observed at 5 days after treatment. The first phase is observed 1 day after inoculation and gives rise to a moderate. This $\mathrm{H}_{2} \mathrm{O}_{2}$ accumulation probably represents an early recognition phenomenon. After this first increase, a second, much larger increase occurs. This accumulation may take place as a response of plant to inducer or pathogen. $\mathrm{H}_{2} \mathrm{O}_{2}$ production during the infection of Arabidopsis thaliana by the soybean cyst nematode Heterodera glycines was detected histochemically by Waetzig et al. (1999). They showed that $\mathrm{H}_{2} \mathrm{O}_{2}$ can be produced by: (1) those cells that were mechanically damaged during invasion and the feeding site induction by the nematode, (2) those cells which surround the developing syncytia, and (3) those cells which were in contact with neither the nematode nor with the syncytium. They also showed that the $\mathrm{H}_{2} \mathrm{O}_{2}$ which is involved in the biphasic oxidative burst is the production of the defense response of $A$. thaliana against $H$. glycines. Sahebani and Hadavi (2009) also showed two distinct phase in $\mathrm{H}_{2} \mathrm{O}_{2}$ accumulation in tomato infected roots with root-knot nematode treated with several chemical and microbial elicitors (BABA, SA and $p$. fluorscens CHA0). They showed a moderate but transient increase during the first phase early after nematode inoculation and a second but much larger increase at 5 days after treatment.

Phenolic compounds are also naturally antifungal compounds and higher accumulation in plants reduces pathogen attack and makes the plants less susceptible to pathogen attack (M'Piga et al. 1997). In our study also, a higher accumulation of phenolic compounds was recorded with BABA application at 7 days interval in cucumber plant against root-knot nematode, $M$. javanica. In addition to direct effects of phenols on pathogens, phenolic compounds are oxidized to form more toxic, quinones, by peroxidases (Gogoi et al. 2001).

Native-PAGE assay indicate that BABA can induce POX isoforms $\left(R_{\mathrm{f}}=0.36\right.$ and 0.39$)$ more than nematode inoculated plants but two other isoforms $\left(R_{\mathrm{f}}=0.31\right.$ and 0.34$)$ are more or less the same in both treatments. Results suggest that isoforms of $R_{\mathrm{f}}=0.36,0.34$ and 0.39 contribute in plant defense programs more than $R_{\mathrm{f}}=0.31$ isoform.

The results of our study suggest that induction of resistance by inducers can be used as an alternative way for managing root-knot nematodes on selected crops and under certain circumstances. Due to the problems caused by chemical control such as their deleterious effects on human health and environment, development of such alternative ways in management of root-knot nematodes and other pathogens is of great importance.

Open Access This article is distributed under the terms of the Creative Commons Attribution Noncommercial License which permits any noncommercial use, distribution, and reproduction in any medium, provided the original author(s) and source are credited.

\section{References}

Avdiushko SA, Ye XS, Kuc J (1993) Detection of several enzymatic activities in leaf prints cucumber plants. Physiol Mol Plant Pathol 42:441-454

Ben Amor N, Ben Hameda K, Debeza A, Grignonb C, Abdelly C (2005) Physiological and antioxidant responses of the perennial halophyte Crithmum maritimum to salinity. Plant Sci 168:889-899

Bradford MM (1979) A rapid and sensitive method for the quantification of microgram quantities of protein utilizing the principle of protein-dye binding. Anal Biochem 72: 248-254

Cohen Y (1994) $\beta$-amino butyric acid induces systemic resistance against Peronospora tabacina. Physiol Mol Plant Pathol 44:273-288

Cooper WR, Jia L, Goggin L (2005) Effects of jasmonate-induced defenses on root-knot nematode infection of resistant and susceptible tomato cultivars. J Chem Ecol 31:1953-1967

Dias MA, Costa MM (1983) Effect of low salt concentrations on nitrate reductase and peroxidase of sugar beet leaves. J Exp Bot 34:537-543

Eisenback JD (1985) Detailed morphology and anatomy of secondstage juveniles, males, and females of the genus Meloidogyne (root-knot nematode). In: Sasser JN, Carter CC (eds) An advanced treatise on meloidogyne, vol 1. North Carolina State University Graphics, Raleigh

Gogoi R, Singh DV, Sivastava KD (2001) Phenolic as a biochemical basis of resistance in wheat against karnal bunt. Plant Pathol 50:470-476 
Gorlach J, Volrath S, Knauf-Beiter G, Hengy G, Beckhove U, Kogel K, Oostendorp M, Staub T, Ward E, Kessmann H, Ryals J (1996) Benzothiadiazole, a novel class of inducers of systemic acquired resistance, activates gene expression and disease resistance in wheat. Plant cell 8:629-643

He CY, Wolyn DJ (2005) Potential role for salicylic acid in induced resistance of asparagus roots to Fusarium oxysporum f.sp. asparagi. Plant Pathol 54:227-232

Hussey RS, Barker KR (1973) A comparison of methods of collecting inocula of Meloidogyne spp., including a new technique. Plant Dis Rep 57:1025-1028

Iiyama K, Lam TB, Stone BA (1994) Covalent cross-links in the cell wall. Plant Physiol 104:315-320

Kato M, Shimizu S (1987) Chlorophyll metabolism in higher plants VII. Chlorophyll degradation in senescing tobacco leaves; phenolic-dependent peroxidative degradation. Can J Bot 65:729-735

Kessmann H, Staub T, Hofmann C, Maetzke T, Herzog J, Ward E, Uknes S, Ryals J (1994) Induction of systemic acquired resistance in plants by chemicals. Ann Rev Phytopathol 32:439-459

Kook Hwang B, Sunwoo JY, Kim YJ, Kim BS (1997) Accumulation of b-1,3-glucanase and chitinase isoforms, and salicylic acid in the DL-b-amino- $n$-butyric acid-induced resistance response of pepper stems to Phytophthora capsici. Physiol Mol Plant Pathol $51: 305-322$

Kvaratskhelia M, Winkel C, Thorneley RNF (1997) Purification and characterization of a novel class III peroxidase isoenzyme from tea leaves. Plant Physiol 114:1237-1245

Lagrimini LM (1991) Wound-induced deposition of polyphenols in transgenic plants overexpressing peroxidase. Plant Physiol 96:577-583

Lamb C, Dixon RA (1997) The oxidative burst in plant disease resistance. Ann Rev Plant Physiol 48:251-275

Lee YK, Hong JK, Sanwald SH, Hwang BK (2000) Histological and ultrastructural comparisons of compatible, incompatible and DL- $\beta$ amino- $n$-butyric acid-induced resistance responses of pepper stems to Phytophthora capsici. Physiol Mol Plant Pathol 57:269-280

M'Piga P, Belanger RR, Paulitz T, Benhamou N (1997) Increased resistance to Fusarium oxysporum f. sp. radicis-lycopersici in tomato plants treated with the endophytic bacterium Pseudomonas fluorescens strain 63-28. Physiol Mol Plant Pathol 50:301-320

Malick CP, Singh MB (1980) Plant enzymology and histo-enzymology. Kalyani Publisher, New Delhi

Mohammadi M, Kazemi H (2002) Changes in peroxidase and polyphenol oxidase activities in susceptible and resistance wheat heads inoculated with Fusarium graminearum and induced resistance. Plant Sci 162:491-498

Monties B (1989) Lignins. In: Dey PM, Harborne JB (eds) Methods plant biochemistry, vol I. Academic Press, London, pp 113-157

Nandi B, Kundu K, Banerjee N, Sinha-Babu SP (2003) Salicylic acidinduced suppression of Meloidogyne incognita infestation of okra and cowpea. Nematology 5:747-752

Oka Y, Cohen Y, Speigel Y (1999) Local and systemic induced resistance to the root-knot nematode in tomato by DL- $\beta$-amino$n$-butyric acid. Phytopathology 89:1138-1143

Oostendorp M, Seikora RA (1990) In vitro interrelationship between rhizospher bacteria and Heterodera schachtii. Rev Nematol 13:269-274

Sahebani N, Hadavi NS (2009) Induction of $\mathrm{H}_{2} \mathrm{O}_{2}$ and related enzymes in tomato roots infected with root knot nematode (M. javanica) by several chemical and microbial elicitors. Biocont Sci Technol 19:301-313

Seevers DM, Daly JM, Catedral FF (1971) The role of peroxidase isozyme in resistance to wheat stem rust disease. Plant Physiol 48:353-360

Shetty NP, Kristensenc BK, Newmana MA, Mollera K, Gregersend PL, Jorgensen HJL (2003) Association of hydrogen peroxide with restriction of Septoria tritici in resistant wheat. Physiol Mol Plant Pathol 62:333-346

Siegrist J, Orober M, Buchenauer H (2000) $\beta$-amino butyric acidmediated enhancement of resistance in tobacco to tobacco mosaic virus depends on the accumulation of salicylic acid. Physiol Mol Plant Pathol 56:95-106

Ton J, Gabor J, Toquin V, Flors V, Iavicoli A, Maeder MN, Metraux JP, Mauch-Mani B (2005) Dissecting the $\beta$-aminobutyric acid-induced priming phenomenon in Arabidopsis. Plant Cell 17:987-999

Vance CP, Kirk TK, Sherwood RT (1980) Lignification as a mechanism of disease resistance. Ann Rev Phytopathol 18:259-288

Velikova V, Yordanov I, Edreva A (2000) Oxidative stress and some antioxidant systems in acid rain-treated bean plants protective role of exogenous polyamines. Plant Sci 151:59-66

Waetzig GH, Sobczak M, Grundler FMW (1999) Localization of hydrogen peroxide during the defense response of Arabidopsis thaliana against the plant-parasitic nematode Heterodera glycines. Nematology 1:681-686

Willekens H, Inze D, Van Montagu M, Van Camp W (1995) Catalases in plants. Mol Breed 1:207-228

Zhang S, Schisler DA, Boehm MJ, Slininger PJ (2007) Utilization of chemical inducers of resistance and Cryptococcus flavescens $\mathrm{OH}$ 182.9 to reduce Fusarium head blight under greenhouse conditions. Biol Cont 42:308-315 